\section{A culture independent method for the detection of Aeromonas sp. from water samples}

\author{
Fadua Latif-Eugenín, \\ Roxana Beaz-Hidalgo, María José \\ Figueras
}

Unit of Microbiology, Medicine and Health Science School, Rovira i Virgili University, Reus, Spain

\section{Abstract}

The genus Aeromonas is present in a wide variety of water environments and is recognised as potentially pathogenic to humans and animals. Members of this genus are often confused with Vibrio when using automated, commercial identification systems that are culture-dependent. This study describes a polymerase chain reaction (PCR) detection method for Aeromonas that is culture-independent and that targets the glycerophospholopid-cholesterol acyltransferase (gcat) gene, which is specific for this genus. The GCAT-PCR was 100\% specific in artificially inoculated water samples, with a detection limit that ranged from 2.5 to $25 \mathrm{cfu} / \mathrm{mL}$. The success at detecting this pathogen in 86 water samples using the GCAT-PCR method was identical to the conventional culturing method when a pre-enrichment step was carried out, yielding $83.7 \%$ positive samples. On the other hand, without a pre-enrichment step, only $77.9 \%$ of the samples were positive by culturing and only $15.1 \%$ with the GCATPCR. However, $83.7 \%$ positive samples were obtained for the GCAT-PCR when the water volume for the DNA extraction was increased from $400 \mu \mathrm{L}$ to $4 \mathrm{~mL}$. The proposed molecular method is much faster ( 5 or $29 \mathrm{~h}$ ) than the culturing method ( 24 or $48 \mathrm{~h}$ ) whether performed directly or after a pre-enrichment step and it will enable the fast detection of Aeromonas in water samples helping to prevent a possible transmission to humans.

\section{Introduction}

The genus Aeromonas currently includes 30 species (Beaz-Hidalgo et al., 2015) that are autochthonous aquatic microorganisms found widely in the environment (Janda and Abbott, 2010; Beaz-Hidalgo and Figueras, 2013; Figueras and Beaz-Hidalgo, 2014, 2015). These bacteria have often been recov- ered from different types of water, such as raw and treated sewage, drinking water, seawater and fresh water (Emekdas et al., 2006; Martone-Rocha et al., 2010; Figueira et al., 2011; Igbinosa and Okoh, 2013; Robertson et al., 2014). Aeromonas is also common in healthy and in diseased fish (Beaz-Hidalgo et al., 2010; Liu and Li, 2012; Chen et al., 2012; Vega-Sánchez et al., 2014), marine mammals (Pérez et al., 2015), chironomid egg masses (Beaz-Hidalgo et al., 2012) and food (CastroEscarpulli et al., 2003; Ottaviani et al., 2006; Nagar et al., 2013). In humans, Aeromonas is recognised as an opportunistic pathogen that can affect both immunocompromised and immunocompetent individuals, with gastroenteritis and wound infections being the most frequent clinical presentations, followed by bacteremia (Janda and Abbott, 2010; Figueras and Beaz-Hidalgo, 2015).

The epidemiological relationships between Aeromonas strains recovered from drinking water and those from cases of diarrhoea have previously been established, thus reinforcing the waterborne and foodborne origin of Aeromonas infections (Khajanchi et al., 2010; Pablos et al., 2011). Therefore, having fast and reliable methods that can trace Aeromonas in water systems is essential because current biochemical methods are time-consuming and not always able to correctly identify the genus, being frequently confused with Vibrio sp. (Chacón et al., 2002; Soler et al., 2002; Lamy et al., 2010). Presently, several genetic markers that allow molecular identification of Aeromonas to genus level have been proposed (Cascón et al., 1997; Chacón et al., 2002; Arora et al., 2006; Balakrishna et al., 2008; Robertson et al., 2014). Among them, there is one that targets the gcat gene (237 bp) that encodes the glycerophospholopid-cholesterol acyl transferase. The latter was developed by Chacón et al. (2002) as an Aeromonas DNA genus probe that specifically hybridised with all 14 Aeromonas species recognised at that time. Later, the protocol was adapted by Soler et al. (2002) for a PCR reaction with an annealing temperature of $56^{\circ} \mathrm{C}$. The gcat gene was characterised by Buckley et al. (1982) as a leading, lethal toxin of the species Aeromonas salmonicida. However, Chacón et al. (2002, 2003) demonstrated that this gene was present in all Aeromonas species and was used as a genus-specific genetic marker in the identification of the isolates in several studies (Chacón et al., 2002, 2003; Soler et al., 2002; Beaz-Hidalgo et al., 2010; Puthucheary et al., 2012). The aim of this study was to adapt the glycerophospholopid-cholesterol acyltransferase-polymerase chain reaction (GCAT-PCR) as a culture-independent method for the direct detection of Aeromonas from water samples.
Correspondence: María José Figueras, Unit of Microbiology, Medicine and Health Science School, Institut d'Investigació Sanitària Pere Virgili (IISPV), Rovira i Virgili University, Sant Llorenç 21, 43201 Reus, Spain.

Tel: +34.9777 .59321 - Fax: +34.9777 .59322$

E-mail:mariajose.figueras@urv.cat

Key words: Detection; GCAT; PCR; Aeromonas; Water.

Conflicts of interest: the authors declare no potential conflict of interest.

Funding: this study was supported by Ministerio de Ciencia e Innovación (Spain), project reference AGL2011-30461-C02-02.

Received for publication: 17 August 2015. Revision received: 27 September 2015. Accepted for publication: 28 September 2015.

This work is licensed under a Creative Commons Attribution-NonCommercial 4.0 International License (CC BY-NC 4.0).

CCopyright F. Latif-Eugenín et al., 2016 Licensee PAGEPress, Italy

Italian Journal of Food Safety 2016; 5:5489

doi:10.4081/ijfs.2016.5489

\section{Materials and Methods}

Polymerase chain reaction specificity and sensitivity in artificially inoculated water samples

Five reference strains (Aeromonas hydrophila CECT $839^{\mathrm{T}}$, Plesiomonas shigelloides CECT 597, Vibrio parahaemolyticus CECT 588, Escherichia coli CECT 744, and Pseudomonas aeruginosa CECT $110^{\mathrm{T}}$ ) were used to evaluate the specificity of the PCR to detect Aeromonas in artificially inoculated, distilled water samples. All strains were inoculated into $10 \mathrm{~mL}$ of Trypticase Soy Broth (TSB; Difco, Leeuwarden, The Netherlands) and incubated at $30^{\circ} \mathrm{C}$ for 24 hours, then concentrations were adjusted to an optical density of 1 (measured with a spectrophometer at 450 $\mathrm{nm}$ ), which corresponded to a concentration of approximately $10^{8} \mathrm{cfu} / \mathrm{mL}$. To verify this, serial 10 -fold dilutions were performed in Buffered Peptone Water (BPW) from $10^{8}$ to $10^{0} \mathrm{cfu} / \mathrm{mL}$ for each strain. From each dilution $(100 \mu \mathrm{L})$ were plated in triplicate onto Trypticase Soy Agar (TSA; Difco) medium and incubated at $30^{\circ} \mathrm{C}$ for 24 hours. The concentration (cfu/mL) of each dilution was estimated by calculating the average of three plate counts. Three flasks (A, B and C) of $100 \mathrm{~mL}$ each of distilled water were artificially inoculated with $1 \mathrm{~mL}$ of a bacterial suspension $\left(10^{8} \mathrm{cfu} / \mathrm{mL}\right)$ that contained: 
A) A. hydrophila CECT $839^{\mathrm{T}}$ alone; B) $A$. hydrophila CECT $839^{\mathrm{T}}$, P. shigelloides CECT 597, V. parahaemolyticus CECT 588, E. coli CECT 744 and $P$. aeruginosa CECT 110; and C) the same microbes as $\mathrm{B}$ but without $A$. hydrophila CECT $839^{\mathrm{T}}$.

From each flask inoculated with the different bacterial mixtures, 10 -fold serial dilutions were performed, and $400 \mu \mathrm{L}$ of each dilution was used for DNA extraction using the InstaGene Matrix (Bio-Rad, Hercules, CA, USA) protocol. The GCAT-PCR amplification was made in a final volume of $50 \mu \mathrm{L}$ containing $5 \mu \mathrm{L}$ of DNA, $1 \mu \mathrm{L}$ of each primer (GCAT-F (5'-CTCCTGGAATCCCAAGTATCAG-3'), and GCAT-R (5'-GGCAGGTTGAACAGCAGTATCT-3') described by Soler et al. (2002) at $15 \mu \mathrm{M}, 5 \mu \mathrm{L}$ of dNTP mix (Applied Biosystems, Carlsbad, CA, USA) at $10 \mathrm{mM}, 0.5 \mu \mathrm{L}$ Taq DNA Polymerase (5 U/ $\mu \mathrm{L}$; Invitrogen, Carlsbad, CA, USA), $5 \mu \mathrm{L}$ of 10X PCR Buffer (Invitrogen), 1.8 $\mu \mathrm{L}$ of $50 \mathrm{mM} \mathrm{MgCl}$ (Invitrogen), and $30.7 \mu \mathrm{L}$ of milliQ water. PCR conditions consisted of an initial denaturation step at $95^{\circ} \mathrm{C}$ for $3 \mathrm{~min}$ followed by 35 cycles of amplification in which denaturation, annealing and elongation temperatures were $94^{\circ} \mathrm{C}$ for $1 \mathrm{~min}, 56^{\circ} \mathrm{C}$ for $1 \mathrm{~min}$, and $72^{\circ} \mathrm{C}$ for $1 \mathrm{~min}$, respectively. A final elongation of $72^{\circ} \mathrm{C}$ for 5 min was included in the programme. Amplification products were analysed on 2\% (w/v) agarose gels in 1X TRIS Borate EDTA (TBE) buffer after staining with Red Safe TM nucleic acid staining solution (INtRON Biotechnology, Seongnam, Korea). Bands at the expected size (237 bp) were considered a positive result.

The sensitivity of the GCAT-PCR was determined by performing dilutions $\left(10^{6}-10^{0}\right)$ of water samples artificially inoculated with Aeromonas (flasks A and B), while the specificity of this method was also assessed by inoculating a bacterial mixture without Aeromonas into distilled water samples (flask C). Furthermore, specificity was corroborated from five randomly selected positive samples from which their bands ( $237 \mathrm{bp}$ ) were cut out and purified using GFX ${ }^{\mathrm{TM}}$ PCR DNA and Gel
(A)

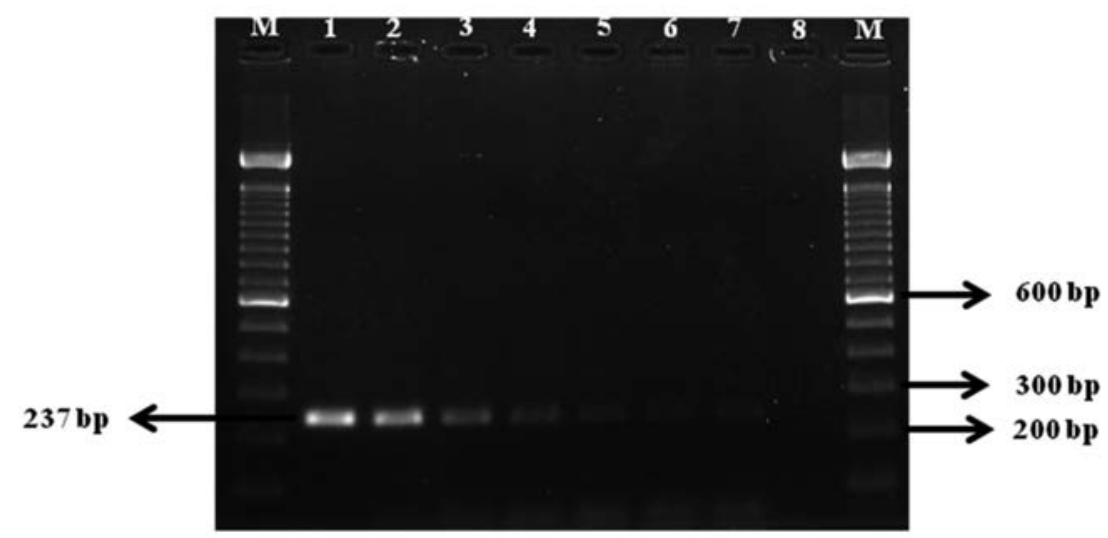

(B)

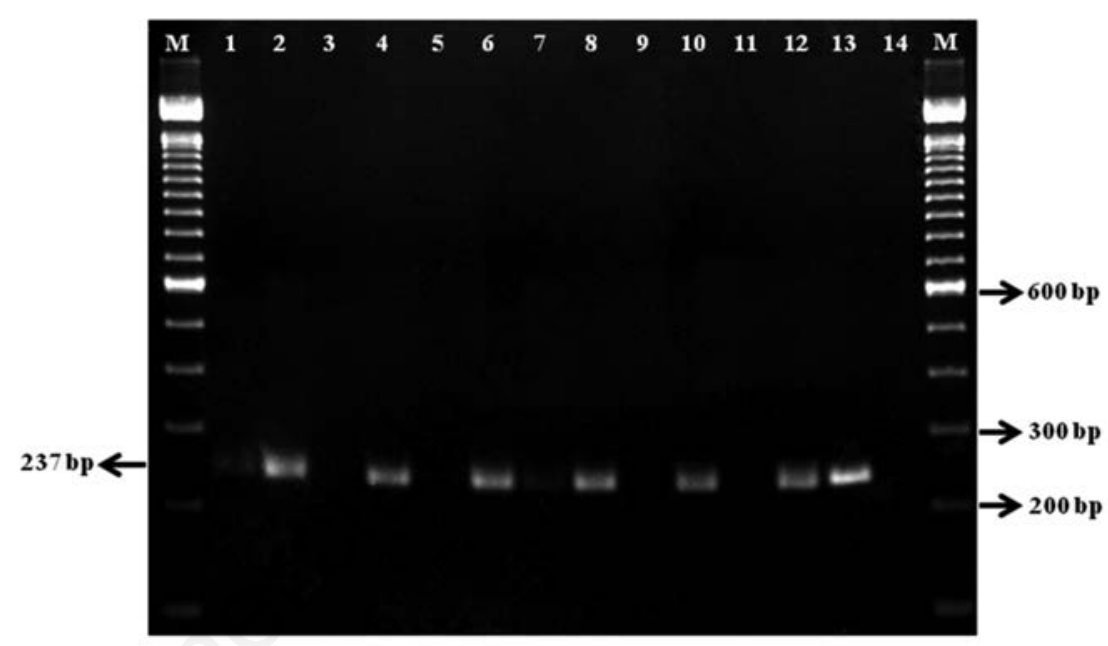

Figure 1. A) Sensitivity and specificity of the glycerophospholopid-cholesterol acyltransferase-polymerase chain reaction (GCAT-PCR) protocol using DNA from the artificially inoculated unenriched distilled water samples with different concentrations of mixed cultures of Aeromonas hydrophila CECT 839 ${ }^{\mathrm{T}}$, Plesiomonas shigelloides CECT 597, Vibrio parahaemolyticus CECT 588, Escherichia coli CECT 744, and Pseudomonas aeruginosa CECT 110T. Lanes: $1-7$, bacterial concentration ranged from $2.5 \times 10^{6}$ to $2.5 \times 10^{0} \mathrm{cfu} / \mathrm{mL}$; 8, negative control; $M$, molecular weight ladder (100 to $2072 \mathrm{bp}$; Invitrogen, Carlsbad, CA, USA). B) Molecular detection of Aeromonas sp. by GCAT-PCR in water samples (lanes 1 to 12). Lanes: 1,3,5,7,9,11, unenriched samples; 2,4,6,8,10,12, enriched samples with alkaline peptone water at $30^{\circ} \mathrm{C}$ for 24 hours; 13 , positive control; 14 , negative control; M, molecular weight ladder (100 to 2072 bp; Invitrogen). Numbers on the left indicate the size of the GCAT amplified product $(237 \mathrm{bp})$, and numbers on the right indicate the position of the molecular size marker.

Table 1. Detection of Aeromonas in eighty-six water samples by culturing and by the glycerophospholopid-cholesterol acyltransferasepolymerase chain reaction.

\begin{tabular}{|c|c|c|c|c|}
\hline \multirow[t]{3}{*}{ Water samples (n) } & \multicolumn{4}{|c|}{ Number of positive samples (\%) } \\
\hline & & & & \\
\hline & Direct & Enrichment & Direct* & Enrichment \\
\hline Sewage (68) & $55(80.9)$ & 60 (88.2) & $12(17.6)$ & $60(88.2)$ \\
\hline River (12) & $12(100)$ & $12(100)$ & $1(8.3)$ & $12(100)$ \\
\hline Sea (6) & $0(0)$ & $0(0)$ & $0(0)$ & $0(0)$ \\
\hline
\end{tabular}

GCAT-PCR, glycerophospholopid-cholesterol acyltransferase-polymerase chain reaction. *These results were obtained when $400 \mu \mathrm{L}$ of water were used for the DNA extraction, but when this water volume was increased 10 -fold $(4 \mathrm{~mL})$ all samples $(72,83.7 \%)$ were positive for the presence of Aeromonas. 
Band Purification Kit (GE Healthcare, Little Chalfont, UK) and sequenced. The identity of the obtained sequences was determined by BLAST with the sequences of the gcat gene deposited in the NCBI database.

\section{Polymerase chain reaction sensitiv- ity in natural water samples}

A total of 86 water samples, including waste water $(\mathrm{n}=68)$, river water $(\mathrm{n}=12)$ and seawater $(n=6)$, were collected from Catalonia, north-east Spain, between February 2012 and September 2013.

Detection of Aeromonas using the GCATPCR (237 bp) in natural water samples was evaluated directly from the DNA extracted from the water, by direct culture incubated at $30^{\circ} \mathrm{C}$ for $24 \mathrm{~h}$ and by culture after an enrichment step at the same incubation conditions. In the case of the direct GCAT detection and direct culturing, $10 \mathrm{~mL}$ of water diluted in $90 \mathrm{~mL}$ of BPW were used to avoid a high bacterial load that could generate too much DNA template and inhibit the PCR reaction. For the enrichment, the same dilution (1:10 vol/vol) was performed in alkaline peptone water (APW-A) supplemented with ampicillin (10 $\mathrm{mg} / \mathrm{L})$ to which almost all Aeromonas are resistant. Finally $100 \mu \mathrm{L}$ of each dilution was inoculated on three culture media Ampicillin Dextrin Agar (ADA), Starch Ampicillin Agar (SAA) and Bile Irgasan Brilliant Green modified (BIBG-m) from which colonies were verified with the GCAT-PCR as was described previously (Soler et al., 2002).

For the molecular detection of Aeromonas sp., $400 \mu \mathrm{L}$ of the enriched and non-enriched samples were used for the DNA extraction to perform the GCAT-PCR as described above. To avoid the different molecules contained in the water samples interfering with the PCR reaction, the pellet obtained after the centrifugation of the $400 \mu \mathrm{L}$ was washed three times using $1 \mathrm{~mL}$ of milliQ water (Millipore, Billerica, MA, USA) each time. For each wash, the pellet was resuspended in $1 \mathrm{~mL}$ of milliQ water and centrifuged at 13.000 RPM for three minutes. In order to study if the non-detection of Aeromonas in many of the non-enriched samples was associated with the water volume used to extract DNA, the latter was increased 10 -fold (from $400 \mu \mathrm{L}$ to $4 \mathrm{~mL}$ ).

\section{Results}

Polymerase chain reaction specificity and sensitivity in artificially inoculated water samples

The DNA extracted from water samples inoculated with $A$. hydrophila CECT $839^{\mathrm{T}}$ yielded the expected amplification product of $237 \mathrm{bp}$ of the
GCAT (Figure 1A) and when this PCR product was sequenced it showed the highest similarity (98-99\%) with sequences of the gcat gene of $A$. hydrophila CAHH2 (KM201324), A. hydrophila CAHH13 (KP159601) and A. veronii B565 (CP002607) deposited in the NCBI database. No amplification was found for the DNA extracted from water inoculated with bacterial mixtures without $A$. hydrophila. The lowest detection limit of Aeromonas in artificially inoculated distilled water samples (flask A and B) ranged between 2.5 and $25 \mathrm{cfu} / \mathrm{mL}$ (Figure 1A).

\section{Polymerase chain reaction sensitiv- ity in natural water samples}

Table 1 shows that $83.7 \%(72 / 86)$ of the water samples were positive for the presence of Aeromonas sp. both by culturing and by the GCAT-PCR method after a pre-enrichment step. Without a pre-enrichment step the number of positive samples was lower, $77.9 \%$ (67/86) by culturing and $15.1 \%(13 / 86)$ by the GCAT-PCR (Figure 1B). To improve these results we increased 10-fold (from $400 \mu \mathrm{L}$ to 4 $\mathrm{mL}$ ) the water volume used for the DNA extraction. This new sample volume was applied to all water samples that showed negative results with the original protocol (using $400 \mu \mathrm{L}$ of the water sample for the DNA extractions) and then all 72 water samples (83.7\%) were positive for the presence of Aeromonas.

\section{Discussion}

This adapted GCAT-PCR method for the direct detection of Aeromonas without culturing, was highly sensitive $(2.5-25 \mathrm{cfu} / \mathrm{mL})$ when distilled water samples were inoculated with $A$. hydrophila CECT $839^{\mathrm{T}}$ alone or together with other bacterial species. These results are similar to those of other studies that have detected Aeromonas (10 cfu/mL or gr) by PCR using $16 \mathrm{~S}$ rRNA and $g y r B$ genes in inoculated food (raw chicken and raw milk) and drinking water samples (Arora et al., 2006; Balakrishna et al., 2008; Robertson et al., 2014).

The $100 \%$ specificity obtained in the present study corroborates previous results, in which colonies or isolates were verified as belonging to the genus Aeromonas when screening for the presence of the gcat gene (Chacón et al., 2002, 2003; Beaz-Hidalgo et al., 2010; Puthucheary et al., 2012).

The same 72 (83.7\%) water samples were positive for Aeromonas after enrichment with APW-A using the GCAT-PCR detection and cultures. However, the sensitivity of the two methods (culturing and molecular) was lower when the samples were not pre-enriched (Table 1) with only $77.9 \%$ of the samples being positive by culturing and only $15.1 \%$ with the
GCAT-PCR. The comparatively poor efficiency of the GCAT-PCR was probably due to the detection limit, because when we increased the water volume for the DNA extraction from $400 \mu \mathrm{L}$ to $4 \mathrm{~mL}$, the percentage of positive samples increased from 15.1 to $83.7 \%$.

The main advantage of the proposed molecular method is that the time required to detect Aeromonas is reduced from 24 hours (culturing method) to only 5 hours (including DNA extraction, PCR and electrophoresis) for the unenriched water.

\section{Conclusions}

Considering that water is the transmission route for Aeromonas infections, this new method will enable fast detection of the bacteria in order to be able to implement strategies that will avoid further dissemination of the bacteria in drinking, irrigating or recreational water systems.

\section{References}

Arora S, Agarwal RK, Bist B, 2006. Comparison of ELISA and PCR vis-à-vis cultural methods for detecting Aeromonas spp. in foods of animal origin. Int $\mathrm{J}$ Food Microbiol 106:177-83.

Balakrishna K, Murali HS, Batra HV, 2008. A novel multiplex polymerase chain reaction for simultaneus detection of Yersinia enterocolitica, Staphylococcus aureus, Aeromonas and Salmonella from chicken meat and milk samples. J Food Safety 30:263-75.

Beaz-Hidalgo R, Alperi A, Buján N, Romalde JL, Figueras MJ, 2010. Comparison of phenotypical and genetic identification of Aeromonas strains isolated from diseased fish. Syst Appl Microbiol 33:149-53.

Beaz-Hidalgo R, Figueras MJ, 2013. Aeromonas spp. whole genomes and virulence factors implicated in fish disease. $\mathrm{J}$ Fish Dis 36:371-88.

Beaz-Hidalgo R, Latif-Eugenín F, Hossain MJ, Berg K, Niemi RM, Rapala J, Lyra C, Liles MR, Figueras MJ, 2015. Aeromonas aquatica sp. nov., Aeromonas finlandiensis sp. nov. and Aeromonas lacus sp. nov. isolated from finnish waters associated with cyanobacterial blooms. Syst Appl Microbiol 38:161-8.

Beaz-Hidalgo R, Shakèd T, Laviad S, Halpern M, Figueras MJ, 2012. Chironomid egg masses harbour the clinical species Aeromonas taiwanensis and Aeromonas sanarellii. FEMS Microbiol Lett 337:48-54. Buckley JT, Halasa H, MacIntyre S, 1982. 
Purification and partial characterization of a bacterial phospholipid: cholesterol acyltransferase. J Biol Chem 257:3320-5.

Cascón Soriano A, Anguita Castillo J, Hernanz Moral C, Sánchez Salazar M, Yugueros Marcos J, Naharro Carrasco G, 1997. RFLPPCR analysis of the aroA gene as a taxonomic tool for the genus Aeromonas. FEMS Microbiol Lett 156:199-204.

Castro-Escarpulli G, Figueras MJ, AguileraArreola G, Soler L, Fernández-Rendón E, Aparicio G0, Guarro J, Chacón MR, 2003. Characterisation of Aeromonas spp. isolated from frozen fish intended for human consumption in Mexico. Int $\mathrm{J}$ Food Microbiol 84:41-9.

Chacón MR, Castro-Escarpulli G, Soler L,Guarro J, Figueras MJ, 2002. A DNA probe specific for Aeromonas colonies. Diagn Micr Infec Dis 44:221-5.

Chacón MR, Figueras MJ, Castro-Escarpulli G, Soler L, Guarro J, 2003. Distribution of virulence genes in clinical and environmental isolates of Aeromonas spp. A Van Leeuw J Microb 84:269-78.

Chen YF, Liang RS, Zhuo XL, Wu XT, Zou JX, 2012. Isolation and characterization of Aeromonas schubertii from diseased snakehead, Channa maculata (Lacepède). J Fish Dis 35:421-30.

Emekdas G, Aslan G, Tezcan S, Serin MS, Yildiz C, Ozturhan H, Durmaz R, 2006. Detection of the frequency, antimicrobial susceptibility, and genotypic discrimination of Aeromonas strains isolated from municipally treated tap water samples by cultivation and AP-PCR. Int $\mathrm{J}$ Food Microbiol 107:310-4.

Figueira V, Vaz-Moreira I, Silva M, Manaia CM, 2011. Diversity and antibiotic resistance of Aeromonas spp. in drinking and waste water treatment plants. Water Res 45:5599-611.

Figueras MJ, Beaz-Hidalgo R, 2014. Aeromonas: detection by cultural and mod- ern techniques. In: Batt C, Tortorello ML, eds. Encyclopedia of food microbiology. Elsevier Ltd, Oxford, UK, pp 25-30.

Figueras MJ, Beaz-Hidalgo R, 2015. Aeromonas infections in humans. In: Graf J, ed. Aeromonas. Caister Academic Press, Norfolk, UK, pp 65-108.

Igbinosa IH, Okoh AI, 2013. Detection and distribution of putative virulence associated genes in Aeromonas species from freshwater and wastewater treatment plant. $\mathbf{J}$ Basic Microb 53:895-901.

Janda JM, Abbott SL, 2010. The genus Aeromonas: taxonomy, pathogenicity, and infection. Clin Microbiol Rev 23:35-73.

Khajanchi BK, Fadl AA, Borchardt MA, Berg RL, Horneman AJ, Stemper ME, Joseph SW, Moyer NP, Sha J, Chopra AK, 2010. Distribution of virulence factors and molecular fingerprinting of Aeromonas species isolates from water and clinical samples: suggestive evidence of water-tohuman transmission. Appl Environ Microb 76:2313-25.

Lamy B, Laurent F, Verdier I, Decousser JW, Lecaillon E, Marchandin H, Roger F, Tigaud S, de Montclos H, colBVH Study Group, Kodjo A, 2010. Accuracy of 6 commercial systems for identifying clinical Aeromonas isolates. Diagn Micr Infec Dis 67:9-14.

Liu JY, Li AH, 2012. First case of Aeromonas schubertii infection in the freshwater cultured snakehead fish, Ophiocephalus argus (Cantor), in China. J Fish Dis 35:335-42.

Martone-Rocha S, Piveli RP, Matté GR, Dória MC, Dropa M, Morita M, Peternella FA, Matté MH, 2010. Dynamics of Aeromonas species isolated from wastewater treatment system. J Water Health 8:703-11.

Nagar V, Shashidhar R, Bandekar JR, 2013. Characterization of Aeromonas strains isolated from Indian foods using rpoD gene sequencing and whole cell protein analysis. World J Microb Biot 29:745-52.

Ottaviani D, Santarelli S, Bacchiocchi S, Masini L, Ghittino C, Bacchiocchi I, 2006. Occurrence and characterization of Aeromonas spp. in mussels from the Adriatic Sea. Food Microbiol 23:418-22.

Pablos M, Huys G, Cnockaert M, RodríguezCalleja JM, Otero A, Santos JA, GarcíaLópez ML, 2011. Identification and epidemiological relationships of Aeromonas isolates from patients with diarrhea, drinking water and foods. Int $\mathrm{J}$ Food Microbiol 147:203-10.

Pérez L, Abarca ML, Latif-Eugenín F, BeazHidalgo R, Figueras MJ, Domingo M, 2015. Aeromonas dhakensis pneumonia and sepsis in a neonate Risso's dolphin (Grampus griseus) from the Mediterranean Sea. Dis Aquat Organ 116:69-74.

Puthucheary SD, Puah SM, Chua KH, 2012. Molecular characterization of clinical isolates of Aeromonas species from Malaysia. PLoS One 7:e30205.

Robertson BK, Harden C, Selvaraju SB, Pradhan S, Yadav JS, 2014. Molecular detection, quantification and toxigenicity profiling of Aeromonas spp. in source and drinking water. Open Microbiol J 8:32-9.

Soler L, Figueras MJ, Chacón MR, Vila J, Marco F, Martinez-Murcia AJ, Guarro J, 2002. Potential virulence and antimicrobial susceptibility of Aeromonas popoffii recovered from freshwater and seawater. FEMS Immunol Med Mic 32:243-7.

Vega-Sánchez V, Latif-Eugenín F, SorianoVargas E, Beaz-Hidalgo R, Figueras MJ, Aguilera-Arreola MG, Castro-Escarpulli G, 2014. Re-identification of Aeromonas isolates from rainbow trout and incidence of class 1 integron and $\beta$-lactamase genes. Vet Microbiol 172:528-33. 